\title{
Governing Juana: Madness and the Manipulation of Power in Three Spanish American Plays on Juana la Loca
}

\section{Kimberle S. López and Angela Marino Segura}

Playwrights not only in Spain, but in Spanish America as well, have long been intrigued by the tale of Juana of Castile. Like Spanish plays, Spanish American works suggest the injustice of the conspiracy to usurp her power and enclose her for half a century in Tordesillas, but also clearly portray Juana as swept away by love sickness, contributing to the popular understanding that her jealous passion drove her mad. Early representations of Queen Juana, such as that found in La locura de amor (Spain, 1855) by Manuel Tamayo y Baus, resurface in the works by contemporary Spanish American playwrights in the form of what we might call generically the "locura de amor" thesis.

By the expression "locura de amor" we are not implying an uncritical stance on Juana's madness; indeed, as Martha Halsey observes, Tamayo y Baus's 1855 play itself examines the political intrigue in which her alleged insanity was used as a pretext to prevent her from exercising her legitimate authority (47-48). Although various characters including her doctor assert that allegations of her madness are slanderous, by the end of Locura de amor, Tamayo's Juana chooses to embrace the label of "loca" and willingly abdicate her authority rather than admit that she has been deceived by her husband both in affairs of state and affairs of the heart.

While many Spanish and Spanish American plays dramatize intricate schemes to depose Juana, most also fundamentally support the notion that she was indeed insanely jealous, as stage directions and dialogue generally direct the actress playing her to perform as a madwoman. Thus, like Tamayo y Baus's mid nineteenth-century play, Spanish American dramatic representations from the latter half of the twentieth century set forth an ambiguous thesis that on the one hand asserts that her madness was invented or exaggerated by 
those who plotted to prevent her from ruling, and on the other hand portrays her as behaving in a manner that contemporary spectators would identify as aberrant.

Like Spanish works, Spanish American plays such as Alberto de Zavalía's El corazón extraviado: Estampas de la vida de la reina doña Juana la Loca (Argentina, 1957), Miguel Sabido's Falsa crónica de Juana la Loca (Mexico, 1985), and Manuel Rueda's Retablo de la pasión y muerte de Juana la Loca (Dominican Republic, 1996) alternately represent Juana's madness as a cause of her loss of authority and as an effect of the political maneuvers of her mother Isabel, her husband Felipe, her father Fernando and her son Carlos.

One of the presumably more objective signs of Juana's madness according to our contemporary sensibilities is her alleged necrophilia, an aspect of her life that is addressed in all three of the plays examined here. In Zavalía's El corazón extraviado, Juana drags her husband's cadaver through Spain on a mad journey with apparently no rational motive. In the plays by Sabido and Rueda, however, there is more questioning of the official history, as both works point out that Juana is not the first widowed royal to escort her spouse's corpse to a distant burial site. As Bethany Aram observes, there was in fact an astute political strategy underlying the historical Juana's endeavor to bury her husband in Granada near her mother Queen Isabel, since it would constitute an important symbolic gesture to legitimize the presence of the Habsburgs throughout Spain, laying the groundwork for their son Carlos's later claims to the imperial throne $(98,170)$. In spite of this logical explanation for the historical Juana's actions, her dramatic portrayal vacillates between affirming her political motives and corroborating the conventional image of the mad queen driven insane by morbid passion.

Another visible sign of Juana's alleged madness both in literary and historical representations is her failure to attend to her external appearance. According to Elaine Showalter, the neglect of personal grooming on the part of women has historically been considered a sign of insanity $(84 ; 212-13)$. The theatrical representation of Juana's disregard for her physical person dates back as far as Tamayo y Baus's 1855 Locura de amor, in which on the very first page unsympathetic characters describe their queen as demented for continually wearing the same torn and tattered dresses and for refusing to eat for days on end. At various points in Sabido's Falsa crónica and Rueda's Retablo, as in Spanish plays such as Benito Pérez Galdós's Santa Juana de Castilla (1918), Ana Diosdado's Los comuneros (1974) and José Martín 
Recuerda's El engañao (1976), Juana appears with her hair uncombed and clothes disheveled as well as talking and behaving in a manner audiences would identify as emotionally unbalanced. While these literary works attempt to vindicate Juana from accusations of madness, the stage directions and dialogue that guide the actress to look and act crazy undermines many of the plays' implicit message that Juana is the only sane person in an insalubrious society that values political ambition over human compassion. In some cases, the fictionalized Juana retains control of her own body to achieve some measure of autonomy, but in none of the plays does she actually succeed in these efforts.

In both the historical record and literary portrayals, when Juana demonstrates an unwillingness or inability to control herself, family members and their representatives step in to forcibly govern her and wrest from her the authority to govern Spain. While Spanish American plays demonstrate how Juana's power was unjustly usurped by kith and kin, Zavalía's El corazón extraviado, Sabido's Falsa crónica, and Rueda's Retablo do not radically contest official history in the sense that they ultimately depict Juana as looking and acting insane.

\section{Governing the Body Politic in Zavalía's El corazón extraviado}

Argentine dramatist Alberto de Zavalía's El corazón extraviado (premiered 1955, published 1957) is the earliest of the plays analyzed here, as well as the most traditional in its structure and theme in that it examines several key events in the life of Queen Juana in chronological order. The sixact play begins with Juana's departure from Spain to wed Felipe el Hermoso, archduke of Burgundy, and continues with her marriage and life abroad. After the death of her mother Isabel and husband Felipe, Juana is enclosed in Tordesillas first by her father Fernando and later by her son Carlos, in order that they may exercise the power that is legitimately hers. Like other plays, El corazón extraviado both questions the official history by representing Juana as prevented from ruling due to unjust constraints placed on her by family members, and acquiesces to the popular understanding of Juana as fundamentally incapable of governing due to a madness caused by passionate and jealous love.

In Zavalía's play, Juana, and later her daughter Catalina, are represented as political pawns, in that the men in their lives use their bodies as a medium of exchange to improve foreign relations among the countries of Europe. ${ }^{1}$ In conversation with her father Fernando, Juana reveals an 
awareness of this use of her body when she refers to herself as "la hija que sólo recordásteis frente a un mapa de Europa" (13). The king's exploitation of Juana's body for political gain is most explicit when he says: "Dueña de tanto ardor encantarás las noches de mi yerno. Y un hombre atado a ese hechizo es más fácil de conducir que un niño" (15). Juana's cognizance of this manipulation again is evident in her response: "Contáis con mis noches para afianzar vuestro pacto con el Imperio...” (15). Later, after Juana arrives in Flanders, the connection between sexuality and politics is further underscored when a newly wed Juana says to her husband Felipe: "tanto vos como yo no somos sino cláusulas de un tratado de alianza" (23). The above leaves no room for doubt that in this depiction, the Catholic monarchs have no scruples about using their daughter's body as part of a larger political strategy to consolidate and extend their European empire.

The notion that the princess needs to learn to govern her emotions if she is ever to rule Spain is introduced at the beginning of the play as Juana bids farewell to her parents before embarking on her voyage to marry Felipe in the Low Countries. As the king of Aragon elaborates, "Vas a ser reina y los reyes tenemos otras emociones que las despedidas familiares. [...] [T]ú debes aprender de mí: nunca he tolerado que un sentimiento me domine" (14). ${ }^{2}$ This leads Juana to inquire, “¿Cómo habéis hecho para gobernar el corazón?” (14), to which Fernando responds, "Siempre quise lo que me convenía querer" (14). As Juana will soon discover, however, her own best interests do not always coincide with her desires, and the discrepancy between these two will lead to problems in Flanders. Notably, her apparent inability to govern her emotions will cause her to be labeled as mad.

One historical episode that is widely interpreted as a sign of Juana's instability occurs after the trip to Spain on which she was named heir to the throne of Castile. Upon her return to Flanders following her forced stay at La Mota, Juana became aware of an apparent affair between her husband and a noblewoman, and she responded by cutting her rival's hair. In El corazón extraviado, Felipe says that a royal personage could not have possibly lowered herself to committing such an affront in her right mind. When Juana offers to apologize, her husband reminds her that a more appropriate response for someone in her position would be to offer her the gift of a pearl necklace Felipe had given his wife. This scene ends with Juana humbling herself by publicly acknowledging her husband's concubine.

In Zavalía's fiction as in other historical and literary representations, Juana's debasement in the hair-cutting episode is taken as an indication of 
emotional instability and consequently used as a justification for controlling her movements. Her behavior has become a cause of concern for the archduke, who tells his wife: "Juana, no podemos continuar así: un escándalo tras otro. Tu conducta insensata nos hace a todos desdichados. Y a ti, también" (32). He proceeds by shutting her out of his heart and his bedroom, leading Juana to abandon her royal dignity by begging Felipe to reciprocate her love in a humiliating scene that is interrupted by the announcement of the death of Queen Isabel of Castile. ${ }^{3}$ El corazón extraviado clearly makes the connection that Juana is led to degrade herself in this manner because of the passion Felipe awakened in her on their wedding night, thus a form of "locura de amor" is at the root of her misfortune.

Cardinal Cisneros asserts that, following her mother's death, Juana allows her husband to govern in her stead because she hopes to conquer his love by abdicating her authority to him. To this, the Admiral of Castile, who near the end of the play admits his long-standing romantic feelings for Juana, responds, "Pero a él no le bastó el gobierno. Quiso ser el único en ceñir la corona y para conseguirlo hasta pretendió encerrar a nuestra Reina en la plaza fuerte de Tordesillas pretextando que su mente desvariaba" (38). Like Tamayo y Baus's Locura de amor written a century earlier, Zavalía's El corazón extraviado represents Juana's enclosure not as an effect of her madness, but of political machinations against her first by her husband, and later by her father. As Felipe lies on his deathbed, Cardinal Cisneros dictates a letter to King Fernando, saying, "Me pregunto si la Reina quedará en condición de gobernar estos reinos, [...] El Rey Don Felipe ha muerto. Ahora nada os separa de vuestra hija...Venid a gobernar sus reinos..." (39-40). Although the Admiral of Castile hopes that the archduke's death will mean Juana's freedom from Felipe's spell, enabling her to take her rightful place as queen of Spain, even this ardent admirer harbors suspicions regarding her emotional wellbeing.

Following Felipe's demise, we witness a conversation among a group of nuns who discuss Juana's apparently irrational decision to drag his corpse through Spain. As discussed above, the historical record indicates that there were valid political motives underlying Juana's choice to accompany her husband's body to bury him in the south of Spain. The nuns in Zavalía's play, however, see this simply as a senseless journey with no apparent destination, the result of the same morbid passion that leads her to open his coffin and kiss Felipe's bloodless lips. The death of her unfaithful husband would presumably liberate Juana from jealousy but instead leads to her descent into madness, as 
she addresses his cadaver, "Ahora sí que eres mío, Felipe. Solamente mío.... [...] Ya nadie puede separarnos. [...] Y tú tampoco puedes huir de mí..." (40). In spite of her statement that death has united them for eternity, Juana expresses the fear that the nuns will approach Felipe, because they are women and consequently subject to sexual desire. ${ }^{4}$ While she is distracted, Cardinal Cisneros urges her father to seize the throne. Thus, like most plays on the topic, El corazón extraviado condemns conspiracies that use Juana's madness as a pretext to usurp her power; nevertheless, her postmortem jealousy is simultaneously represented as a genuine indication of her inability to govern herself or others due to a paralyzing love sickness.

As in later plays by Sabido and Rueda, in El corazón extraviado Juana makes a forceful declaration of her capacity to rule, as she tells Cardinal Cisneros, "Estoy dispuesta a gobernar sin personeros. ¿Entendido?" (44). Zavalía's Juana appears lucid when she announces her plan to rule her realms herself, but her father Fernando finally admits she is out of touch with reality when she tells others not to pray too loudly so as to avoid waking her husband. Not only does the king of Aragon usurp Juana's legitimate power, but he also reveals his intention to once again use his widowed daughter's body as a site to negotiate foreign affairs when he proposes marrying her off to King Henry VII of England, a marriage that was in reality proposed but rejected by the historical Juana of Castile (Aram 101). ${ }^{5}$ Soon it becomes clear that the only realm that Juana will occupy will be the retreat at Tordesillas, where she will not rule but will be ruled first by her father and later her son.

The final act takes place after Juana and her daughter Catalina have been living in Tordesillas for twelve years, and her son Carlos comes to visit. The Holy Roman Emperor claims that he has come to obey his mother's will, if indeed she is of sound mind, asserting, "No deseo ceñir la corona si la Reina puede soportarla" (56). Juana, however, fails to recognize her old friend the Admiral of Castile, leading even her staunchest supporter to doubt her sanity. Significantly, she also disavows her own authority, saying "No tengo vasallos, ni tampoco corona" (57), and offers Carlos her throne: "¿Y vos queréis gobernar? (Pausa breve.) Hacedlo en mi nombre...O, si preferís, llamaos Rey de Castilla y de Aragón" (59). Carlos claims, "No fueron el Rey Fernando ni Cisneros quienes la encerraron. Fue ella misma...Nadie la privó de su corona, ella no la quiso ceñir..." (59). This parallels other dramatic works that feature Juana herself renouncing her throne.

By the end of the play, the Admiral of Castile, who is biased due to an undying love for Juana, is the lone defender of the position that Juana's 
madness was used illicitly to usurp her authority: "Su mal era curable, estoy seguro; pero todos se confabularon para que no tuviese remedio... ¡Pobre España!" (59). The final act ends just after Carlos has abducted his sister Catalina, presumably with the intention of marrying her off to a foreign prince. The play thus comes full circle in that it begins with Juana's body being used as part of a strategy of foreign relations, and ends with the implication that Catalina's body will be used for a similar political purpose. ${ }^{6}$

Like later works, while Zavalía's play suggests a conspiracy to seize Juana's power, this perspective is not consistently upheld by the plot elements. El corazón extraviado portrays Juana as a queen whose authority is illegitimately appropriated by the politically ambitious men in her life, but also paradoxically justifies this usurpation by portraying Juana as unable to monitor her own words and deeds, leading those around her to assert that rather than being able to govern Spain and its territories, she herself needs to be governed. Furthermore, the audience witnesses Zavalía's Juana voluntarily relinquishing her own authority, so it is difficult for the objective observer to give credence to the opinion expressed by a minority of characters that she is not insane but instead the victim of an elaborate plot. Thus, like other plays, El corazón extraviado introduces the notion that Juana's madness is manipulated by those around her as a pretext to usurp her authority, and yet does not ultimately challenge the notion of her insanity itself.

\section{Grooming Juana in Sabido's Falsa crónica de Juana la Loca}

In Falsa crónica de Juana la Loca (1985), Mexican dramatist Miguel Sabido goes further than other Spanish American playwrights in terms of both theatrical innovation and thematic contestation of the conventional image of the mad queen. Sabido's seven-scene play deviates from a linear chronology, since Juana's handsome husband is dead from the beginning, but a series of flashback and flashforward sequences reconstruct the story of her marriage, widowhood, and lifelong seclusion. In his own introductory analysis to the play, Sabido explicitly declares his intention to break with official history by suggesting that the real Juana of Castile did not go mad until after having suffered the triple injury of the intent to dethrone her by her husband Felipe, her father Fernando, and her son Carlos, aided by representatives ("Algunas interrogantes" 9). Each of these powerful men in turn attempts to silence and govern Juana in order to win her cooperation in naming him as ruler. By examining these successive schemes, Sabido implies that Juana's "madness" was an effect rather than a cause of her loss of authority. Nevertheless, like 
other plays that treat the same topic, Falsa crónica presents an ambiguous portrayal of the so-called mad queen.

One of the most outrageous theatrical elements of Sabido's play is that stage directions indicate that Juana be yoked to a cart and haul Felipe's corpse around the stage during a significant portion of the action. The introductory essay clarifies Sabido's position on Juana's motives for transporting her husband's body through Spain: "El propio viaje con el cadáver de Felipe puede explicarse como una medida estratégica mejor que como un acto de necrofilia" ("Algunas interrogantes" 9). Thus, as Sharon Magnarelli observes, Sabido challenges the official history that silenced Juana and declared her unfit to rule: "[W]hile he perhaps accepts the veracity of Juana's final madness, [Sabido] does not endorse the official version of that insanity; instead he offers an alternative interpretation, particularly of those events which have been officially proffered as proof of her derangement" (50).

In dialogue, Sabido's Juana herself articulates sound political reasons for transporting Felipe's corpse through Spain: "Buscaba llegar al Sur para obtener el apoyo de los grandes de Andalucía para defenderme de mi propio padre. Isabel pidió que nos enterraran en Andalucía, el reino que ella había reconquistado. Dos años antes el cadáver de mi madre viajó por toda España para reposar en Granada y nadie acusó a mi padre de loco por llevarla" (79). These words are expressed near the end of the play, however, whereas in earlier scenes, Juana repeatedly states that she is aware of her husband's death but offers no satisfactory explanation for transporting his body. At the same time a female dwarf undermines her assertions by claiming that lugging the rotting corpse around proves that Juana holds to a false belief that Felipe is just sleeping. When Juana orders her attendants to ask his lordship for instructions regarding dining, this would seem to confirm other characters' claims that she is deranged. In light of these contradictory words and acts, it would require a great deal of intellectual effort on the part of Sabido's audience to interpret the overwhelmingly dramatic image of the widowed queen physically dragging her husband's coffin around the stage as a political act rather than a gesture of lunacy.

Like other plays, Falsa crónica specifically points to a theory of love sickness. The female dwarf says "Todo el mundo sabía/que la reina Juana de amor por el rey Felipe fenecía" (21). This idea is supported by Juana's own words directed to her dead husband: "Tú, la única razón de cualquier existencia; [...] Tú, mi sexo; Tú, mi locura" (20). This declaration seems to indicate an undying and unhealthy passion. Like Zavalía's El corazón 
extraviado, Falsa crónica sustains the "locura de amor" thesis by suggesting that by awakening Juana's sexuality, Felipe also drove her insane with amorous passion. Sabido's prologue itself contradictorily states, "Está loca. Es una loca de amor [...] y quizá, no está loca" (16). While these inconsistencies can be perceived by the literary critic as part of the playwright's endeavor to subvert the broader notion of power, the spectator who sees the play presented on stage without benefit of having read Sabido's introductory essay and prologue would be likely to interpret this behavior and dialogue as unequivocal signs of madness.

As mentioned above, Sabido explicitly posits the notion that the political ambitions of her husband, father, and son drove the queen to madness. Early in the play, King Fernando is represented as a puppet master manipulating the lives and bodies of his children and grandchildren by arranging marriages that benefit Spain's foreign relations. Love is subordinate to politics for all but Juana, as one of the courtiers says, "esto es alta política querida mía. [...] [A] nadie le interesa el amor" (37). Adding a sinister quality to the game, Death plays with the Machiavellian king, choosing to pick off each of Fernando and Isabel's heirs one by one. As Becky Boling observes, "In this way, Sabido creates a carnivalesque setting for the discussion of power" (89). As in other literary representations, the Catholic monarchs are depicted here as subordinating their offspring's happiness to political advantage.

Although she is deceased before the beginning of the play, Queen Isabel returns to torment her daughter by constantly reminding her that her duty is to turn a blind eye to Felipe's infidelity and sacrifice her happiness for the sake of her subjects. One historical episode mentioned, but not represented on stage, involves Juana's outburst against her mother at La Mota where the heiress apparent was being held against her will after her husband returned to his homeland. Whereas Aram's historical text indicates that the princess's reaction can be interpreted as a form of resistance against her captivity and forced separation from her spouse, in Sabido's play, no logical explanation is proposed to offset the impression that Juana behaved violently toward her mother simply because she is unbalanced. In addition, even a reader or spectator predisposed to believe in Juana's sanity would have difficulty refuting the chorus of voices laughing and shouting that the archduchess howls in the night like an animal. Rather, much of the evidence would seem to point to the standard diagnosis of "locura de amor."

Juana herself confirms the anonymous voices' assertions that she has tried myriad strategies including witch's spells and her own feminine 
wiles to entice her husband to love her. Sabido downplays the historical episode most often offered as evidence of Juana's jealous rage, the shearing of her rival's locks, by only mentioning it in passing rather than exploiting the incident's dramatic potential. In contrast, a whole scene is devoted to a fictional episode in which Juana procures the aid of a witch in a vain attempt to seduce Felipe. As in other works such as Tamayo y Baus's Locura de amor, Sabido's Juana herself accepts the label of madness: "Llevaos a los reales infantes de aquí, que no vean a su madre loca. Loca de amor, loca de abandono, loca de ausencia" (44).

As the story of her marital discord develops, Felipe makes love to his paramour on stage right in front of his wife, and then accuses Juana of irrational jealousy and unbecoming conduct: "Te tiras al suelo como una niña caprichuda, te bañas tres veces al día, te niegas a comer, te rehusas a dormir porque no estoy presente" (47). Here the archduke's implication is that Juana's inability to govern her own behavior casts doubt on whether she could effectively govern anyone else. ${ }^{7}$ When Felipe asks her to sign her power over to him, however, Juana defiantly replies, "¿Me vendes el placer de tu lecho por un reino? ¡Qué barato!" (47). In a later flashback, Juana confidently informs Felipe:

Se trata de que soy española y soy reina. Y quiero avisaros que ha terminado ya la esposa sumisa y fiel que fue a buscaros a Flandes. Esa princesita insignificante y torpe, que esperaba ser feliz al lado de Felipe, ha muerto. Soy una reina y tengo deberes...y voy a cumplir esos deberes pase lo que pase. (63-64)

In these bold statements, her lucidity would seem to refute the accusations of madness.

Notably, Juana's neglect of her physical person can alternately be interpreted as a form of resistance or as a sign of her inability to govern herself. These interpretive possibilities are highlighted in scene four of Sabido's play, which opens with the captive Juana in a nightgown with her hair uncombed refusing a plate of food while a chorus of courtiers comments on the scandal her conduct will cause. Juana adamantly declares that she will not eat, bathe, or comb her hair until her father comes to visit her in Tordesillas. The historical record suggests that "Juana protested the seizure of her son [Fernando] and the imposition of new household personnel by refusing to eat, dress, wash, and worship appropriately. Since her father's departure [...] Juana had not changed her shirt or headdress, washed her face, or slept in a bed" (Aram 100). This use of her own body as a form of resistance is reminiscent of the medieval 
"fasting saints" who are said to be the predecessors of today's anorexics, in that they controlled their own bodies in response to a lack of control over other aspects of their lives; but like her contemporary equivalents, Juana mostly harmed herself through such efforts. ${ }^{8}$

Indeed, this episode was used to the detriment of the historical Juana, ${ }^{9}$ even though her mother had effectively employed her own body in a similar fashion for political ends: "Juana's defiant conduct, reminiscent of Queen Isabel of Castile's supposed refusal to change her shirt until the fall of Granada, may also have been calculated to demand Fernando's attention" (Aram 100). Ironically, while a comparable tactic was used, the effect was the opposite for mother and daughter. Significantly, whereas Isabel's refusal to wear clean garments until the reconquest was complete constituted a shrewd strategic move, a coup of political propaganda resulting in an enhancement of the Catholic queen's public image, Juana's parallel effort contributed to the impression of her madness. Perhaps this difference can be explained by the notion that while she inherited her realms, Juana apparently did not inherit an adequate share of Isabel's considerable personal charisma and political savoir faire. As a result, the real Juana's neglect of personal grooming, like that of her fictionalized homonyms, ultimately served less to register a protest against an unjust confinement, and more as a means for her jailors to justify the legitimacy of her enclosure on the grounds that she was indeed mad.

Sabido's Juana does manage to gain her father's attention, but the king responds by using psychological extortion to persuade his widowed daughter to sign her power over to him: “ ¿Si te niegas a casarte de nuevo, [...] si te niegas a nombrarme a mí como regente, qué es lo que quieres hacer? ¿No pensarás reinar por ti misma?" (71). In a previous scene, Juana had soberly articulated her refusal to conform to a society that prioritizes political ambition over human values: "Yo soy una mujer, no un peón en una partida de ajedrez. ¿Qué me importan tus juegos, padre? ¿Tus combinaciones y maquinaciones? ¿No te das cuenta que tus hijos somos seres humanos? [...] No somos títeres." (61). Here, in contrast, we see Juana's utter impotence, as she responds to her father, "Todos dicen que estoy loca. [...] ¿Estoy loca?" (71). The titular queen exercises so little power that she does not even have her own body at her disposal. When she says she wishes she could die, her father responds that death is a luxury she cannot afford, since it would expose Spain to a foreign invasion. Because the king's right to rule Castile depends on his daughter being alive but incapacitated, this fictionalized Fernando attempts to persuade her that she is indeed mad, and he seems to have succeeded, since this scene 
ends with Juana questioning her own sanity and, dressed in a torn nightgown, yoking herself once again to the cart bearing Felipe's rotting corpse.

Years later, when her son Carlos visits Juana in Tordesillas seeking her public acknowledgement of his sole reign of the empire, he encounters a mature and capable Juana who reminds her son of her rightful place with uncharacteristic force: "La reina de España soy yo. Mi madre me heredó la corona de Castilla...de España y de las Indias Occidentales" (77). The conversation continues:

CARLOS: Todo el mundo sabe vuestra condición señora.

JUANA: (Perfectamente lúcida). ¿Que estoy loca? Juana la Loca, loca de amor. ¿Que mi padre me encerró por loca? No, hijo...mi padre me encerró para reinar en mi nombre porque [...] tenía miedo de que su imperio se desmembrara. [...] Nunca te pusiste a pensar....[q]ue tu madre, que Europa entera reputaba como loca...no lo estuviera?

CARLOS: Tu propio padre lo gritó en toda Europa. [...] Tu propio esposo te acusó de loca.

JUANA: Para quitarme el trono que me heredó mi madre; como tú lo haces ahora. (78-79)

Here Juana is given voice to directly confront the official story, and she demonstrates a lucid understanding of the political motivations behind her prolonged confinement.

Despite Juana's keen assessments, Carlos equates his mother's resistance with uncontrolled passion: "El mundo entero tiene razón: estáis completamente loca" (82). To this, Juana retorts, "No es cierto...Me volverás loca si me dejas encerrada en esta torre...me volverán loca a fuerza de tratarme como loca" (82). Significantly, when Juana asserts, "Carlos...no estoy loca...," her son reveals his true motives by declaring: "Lo estáis: por razones de Estado" (83).

It eventually becomes clear that Juana's ideological perspective is at the root of the Holy Roman Emperor's accusation of her madness, which in turn is used as a justification to sabotage her power. Specifically, Juana manifests an anti-imperialist viewpoint when she overtly criticizes the Habsburg project of colonization: "Cada país tiene derecho a tener su propio rey y su propia manera de entender la obra divina de Dios. ¿Por qué ha de haber un emperador que se crea con derecho a dominar a todos los países?" (82). As Boling observes in reference to Sabido's play, "Juana's madness is just the name for an ideology that is proscribed" (92). 
In Falsa crónica de Juana la Loca, madness is represented as a label conveniently employed in order to govern Juana and prevent her from governing. Although each of the men in her life succeeds in achieving some degree of power over her, Sabido's Juana manages to voice her noncompliance with the goals of empire by valorizing love above political ambition. While the prologue and seven scenes that compose the play vacillate on the question of her madness, by the end, Juana demonstrates her moral superiority by subversively challenging the mechanisms of power.

\section{Gaslighting Juana in Rueda's Retablo de la pasión y muerte de Juana la Loca}

Dominican author Manuel Rueda's Retablo de la pasión y muerte de Juana la Loca (Premio Tirso de Molina 1995, published 1996) is a twoact play whose primary time frame representing Juana's imprisonment in Tordesillas is interrupted by numerous flashbacks to key moments in the life of the so-called mad queen. Retablo begins by asking whether in fact the queen is mad; although the play does not answer the question, it does examine the issue from a variety of perspectives through the political and philosophical opinions of a Spanish chorus and Flemish chorus and observers such as Erasmus and Machiavelli who appear periodically to debate the issue of the mad queen. As in the other plays discussed here, Retablo suggests that Juana's madness may not be a cause, but rather a result, of the fact that she is governed rather than governing; but in the end, the text does not absolutely contradict the popular notion that she was indeed emotionally unstable.

Rueda's Retablo begins with Juana's imprisonment at the hands of her father. In the play, as in real life, the queen is enclosed in Tordesillas accompanied by her husband's corpse, since she did not complete her intended journey south to bury him in Granada near her mother. ${ }^{10}$ Like Sabido's protagonist, Rueda's Juana observes that she is not the only one to escort a royal spouse's corpse. When King Fernando asks, echoing the spectator's concerns, “¿Por qué ese espectáculo macabro?” (20), his daughter responds, "¿No hicisteis lo mismo con mi madre? ¿No atravesó ella, muerta, toda la extensión de su reino para ir a enterrarse en Granada, el último bastión de su conquista?" (21). Although it engages this issue, Rueda's play actually does less to illuminate Juana's motives than Sabido had done a decade earlier.

As do earlier plays dating as far back as Tamayo y Baus's 1855 Locura de amor, Rueda's Retablo suggests that Juana was the object of a conspiracy to which she fell victim due to her valorization of love over politics. Like 
Sabido's Falsa crónica, Rueda's Retablo does represent Juana acting in a manner that might lead the spectator to conclude that she is indeed mad, for example, behaving as if her husband's cadaver were sentient even though she knows he is dead. But it is also insinuated that she is a victim of the manipulation of power by important males in her life. Speaking to her father, Rueda's Juana asserts that what constitutes true madness is the prioritization of political ambition above human values: "Sí, la verdadera locura es la vuestra. ¡Cuánta ansia de poder hay en vuestro corazón! ¿Qué más queréis? Ya he dejado de ser una contrincante para vos" (16). Here Rueda reiterates Sabido's thesis that Juana's love established her moral superiority at the same time as it led to her downfall in material terms.

Although Rueda's emphasis is on the male family members who usurp Juana's authority, Queen Isabel is also represented as one of the people impeding her freedom of movement: "¿no fue ella también mi carcelera, al igual que Felipe y al igual que lo sería después mi padre?” (34). As Juana protests to King Fernando:

Padre, mi vida ha sido una sucesión de prisiones: he estado presa de mi madre en La Mota, presa de Felipe en Bruselas, y ahora estoy presa de vos en Tordesillas. [...] Los que más he amado son mis crueles verdugos. Oh, padre, por vos he estado siempre dispuesta a dar la vida, y, sin embargo, me rebelo cuando me quitáis la libertad. ¿Qué más queréis de mí? Os he dado poderes para que gobernéis en mi nombre. (21-22)

As Aram points out in reference to the historical Juana of Castile, here the fictionalized queen's household and person are administered by her family members, servants, diplomats, and clergymen. ${ }^{11}$ Juana poignantly summarizes, “iQué excelentes carceleros han resultado ser mis padres!" (37).

As Aram notes is the case of the historical Juana, here it is clear that the queen is not even in charge of her own household, much less her country; rather, she is governed by various others who limit her movement as well as her contact with the outside world. In a flashback to La Mota, Juana is aware of concerted efforts to control her mobility, although not without the princess resisting the servants who feel empowered to govern her: "Doña María, ¿me estáis dando órdenes?" (41). ${ }^{12}$ She realizes that she cannot even trust her own ladies in waiting, because everyone around her acts in complicity to restrict her movement. ${ }^{13}$

Although the "locura de amor" thesis is emphasized less here than in other plays, while she is captive at La Mota, Rueda's Juana is concerned that 
Felipe is committing adultery back in the Low Countries. As in other historical and literary representations, upon her return to Flanders, she punishes her suspected rival by cutting her cheek, cutting off her hair, and forcing her to eat a love letter from Felipe. Following this scene the Flemish chorus declares Juana mad and proclaims that the archduke is justified in confining her. Furthermore, for the chorus, an incontrovertible proof of Juana's madness is the fact that while Felipe was beating her and dragging her on the floor as a result of her revenge against her rival, she responded by kissing his hands and begging his forgiveness. ${ }^{14}$

In Rueda's version, various attendants are employed to control Juana's contact with the outside world to the extent of "gaslighting" her. ${ }^{15}$ When the king of Aragon leaves his daughter to her fate in Tordesillas, Cardinal Cisneros is one of those used to maintain surveillance over the deposed queen and scrutinize the information she receives from beyond the palace walls. Juana calls attention to the cardinal's encroachment on her authority: "Pronto habéis aprendido a dar órdenes a la reina de Castilla" (17). While she acknowledges that inevitably she will be deprived of her freedom, she makes certain to register the fact that she recognizes the manifest injustice of her treatment, given that she is by this time the titular queen of Spain.

After Rueda's Juana has been captive in Tordesillas for a dozen years, she has a conversation with her confessor, who observes, "El poder es una carga demasiado pesada para vuestros hombros" (58), thus confirming the standard interpretation that Juana is not strong enough to rule. She even questions her own sanity: "Abandonada por mi padre, por mi marido y por Dios, ¿qué me queda sino enloquecer? [...] Padre, ¿creéis que en verdad estoy loca? (58). As in other plays, here Juana is aware of claims of her madness, and attempts to address them, although no definitive conclusion is reached. The "locura de amor" thesis is engaged when Juana launches into an extensive monologue in which she says that only in death could her husband be truly hers, since he was unfaithful to her in life. Juana remembers a dying Felipe whispering in her ear the claim that King Fernando had poisoned him, but then she doubts her own memory, saying, "¿Fue esto cierto o tal vez lo he inventado como dicen que hago con tantas cosas?" (59). Here again, Rueda implicitly points to the idea that Juana is the victim of "gaslighting," in that those around her constantly deceive her, leading her to question the accuracy of her own memory.

When Carlos visits Tordesillas, he speaks of arranging a marriage between his sister Catalina and a foreign ruler to improve Spain's European 
relations, asserting that his mother should leave this matter in his hands. Juana replies with a declarative statement that echoes the representation of this same encounter in Sabido's earlier play: "La reina de España soy yo, tened esto bien en cuenta" (62). The strength of will demonstrated in this effort to protect her youngest daughter from being used as a political pawn, however, is undermined in the dialogue that follows, when Juana tells her son that it would be good for her father to visit her as well. Carlos reacts with surprise, saying that in her confusion she has forgotten that King Fernando has been dead for years. ${ }^{16}$ Juana collapses and tells her son, "Sin duda, me engañáis" (63), leading Carlos to speculate, "No habrán querido inquietaros con la noticia" (63), to which Juana responds, "La inquietud es lo primero que me proporcionan mis carceleros" (63). While other scenes in Retablo implicitly refer to Juana's "gaslighting," here is where it is engaged most explicitly. In the above exchange, it is clear that as in history, Carlos's representative the Marquis of Denia is controlling the information that Juana receives, thereby creating an artificial world for her to inhabit. ${ }^{17}$

In Rueda's play, Carlos is at first unaware of Denia's deception, but by the end of the visit, Juana has alternated between lucidity and delirium to the extent that her son agrees that it is necessary to control Juana's mobility and access to information. As Rueda's Carlos says to Denia:

No tenéis nada más que decirme, ya lo he comprendido todo. Encerradla, encerradla en la habitación más aislada que tengáis, adonde no debe llegar ni el más leve rumor del mundo. Quedan definitivamente prohibidas las visitas de cortesía. Tendremos una constante comunicación entre los dos. ¡Velad, velad siempre! Os recompensaré por ello. (64)

Thus is born the complicity to govern Juana, as the emperor urges the marquis, "Y tratad de que firme los poderes que necesito para gobernar este difícil país que me ha tocado en suerte" (64). What Juana had said in a previous scene about political ambition being the true sign of madness could be applied here to her son as earlier to her father, since it is clear that the declaration of madness and consequent enclosure of the queen serves Carlos's political interests.

As in other literary and historical depictions, in Rueda's play Juana's personal comportment and lack of attention to grooming are interpreted by others as indications of madness. First at La Mota, and later at Tordesillas, Juana is portrayed like a doll or a puppet, passively allowing her servants to arrange her hair and dress her only when she receives a royal visit, while 
the rest of the time she remains in a disheveled state. When Carlos's visit is announced, Denia commands her attendants, "Apuraos. Y, sobre todo, ponedla presentable. Desde hace tiempo ha descuidado su apariencia y su aseo. Más bien parece una moza de figón que una alteza real" (61). In the final scene, we see her with unkempt gray hair, refusing to eat, throwing her plate of food then bending down to pick it up, and waiting to die. In spite of the play's generally compassionate portrayal of Juana, the implication here would seem to be that her inability to govern her own body serves as a sign of insanity and consequently as an indication of her inability to rule the country. ${ }^{18}$

As with the other texts analyzed here, Rueda's play sheds light on the political ambitions that motivate Juana's family members to constrain her movement and communication, and examines the issue of her madness from various perspectives. Ultimately, however, Retablo portrays her speaking and acting in a way the audience would tend to identify as unbalanced, thus implicitly justifying the successive decisions of her mother, her husband, her father, and her son to "govern Juana."

Although Zavalía, Sabido, and Rueda propose challenges to the popular lore of Juana's "locura de amor," they nevertheless fundamentally retain underlying assumptions regarding her mental instability, which leads them to negotiate and at times compromise with the official history. Notably, these three Spanish American playwrights create sympathetic portrayals of protagonist Juana of Castile that strive to offer alternatives to unidimensional representations of this figure but ultimately do not radically contest the basic notion of her madness. Thus, El corazón extraviado, Falsa crónica, and Retablo, to varying extents, paradoxically both resist and reinforce the image of the queen driven insane by unrequited passion.

\section{University of New Mexico and New York University}

\section{Notes}

See Rubin, Gallop, and Sedgwick on the topic of women as objects of exchange used to consolidate social relations between men.

2 There is a historical inaccuracy here in that upon embarking for Flanders, Juana was not expected to be queen of Spain because at that time her brother and older sister, as well as potential nephews yet to be born, stood between her and the throne.

3 According to Aram, after disputes following her return to Flanders, the historical Felipe locked Juana in her chambers and refused to see her: "The princess, in turn, allegedly spent an entire night 
pounding on the floor of her bedroom and the ceiling of Philippe's, demanding her husband's attention. She refused, moreover, to eat a bite of food until the prince agreed to speak with her" (77).

${ }_{4}$ Part of the popular lore surrounding the figure of the mad queen revolves around the jealousy that supposedly led her to prevent other women from approaching Felipe's corpse. Aram dispels this allegation by explaining that Felipe's body was taken to a male monastery in which nonroyal women were not permitted (89). Zavalía's El corazón extraviado, however, has the corpse housed in a convent and consequently represents Juana's jealousy of the nuns as irrational.

5 As Aram observes, the king of Aragon ostensibly supported this marriage proposal but in reality sought to undermine it (101-02).

6 Carlos did in fact abduct his youngest sister in 1518 but was forced to return her to Tordesillas a few days later because Juana had gone on a hunger strike (Aram 118). In 1525, the emperor arranged for her to marry the king of Portugal (Aram 131-32).

7 According to Elaine Showalter, paradoxically, both neglect of personal appearance and excessive attention to grooming have been perceived historically as signs of female madness (84).

8 Joan Jacobs Brumberg notes that "[t]oday's anorectic is one of a long line of women and girls throughout history who have used control of appetite, food, and the body as a focus of their symbolic language," a language that is related to a "confused desire for autonomy and control" $(2,16)$. As Walter Vandereycken and Ron Van Deth observe, "[a]lthough fasting saints, miraculous maidens, hunger strikers, and anorexics differ in many respects they have one thing in common: all have relatively little power. Self-starvation is one means of acquiring it. But however influential a 'weapon' it may be, it should also be seen as a double-edged sword: the psychological and physical self-injuries it may cause are no small price to pay for self-assertion!" (225). According to Showalter's Female Malady, madness itself has been considered by some as a form of resistance against traditional gender roles, in the face of "the constraints of a narrow femininity" (4), but the critic warns of the danger of romanticizing madness as a positive form of rebellion (5). Showalter explains that using behavior labeled as insane did not empower women effectively, since as a means of resistance directed toward the patriarchal order, "hysteria was at best a private, ineffectual response to the frustrations of women's lives" (161).

9 As Aram summarizes, "The bishop provided this portrait of a disorderly queen - flagrantly disrupting household routines - in order to encourage Fernando to return to Castile. [. . .] Begging the king to intervene, Ramírez de Villaescusa argued that Juana could not govern her body, much less her subjects. [...] [H]er reported behavior violated royal, and even civilized, norms" (100).

${ }_{10}$ As Aram documents, "[t]hroughout 1508 Juana and Fernando vied for control over Philippe's corpse. [...]. The Aragonese king simultaneously aspired to move Juana from the Arcos palace to a more secure residence in the town of Tordesillas [...] Yet the queen herself refused to budge without Philippe's corpse" (99). Aram continues, “Apparently, Juana agreed to move to Tordesillas if she could take Philippe's remains with her. [...] In the words of a Venetian ambassador, 'Her Majesty the queen will not go without the body" (100-01).

${ }^{11}$ Aram concludes, "[t]he sources have pushed me to see Juana's 'madness' as a product as well as a cause of conflict with attendants who supposedly served her" (168).

12 This is reminiscent of a scene in Tamayo y Baus's Locura de amor, in which Juana reproaches her servant: "¿Sabes que quien no nos conociese te tomaría por la señora? Que yo lo soy recuerda" (18).

${ }_{13}$ As Aram observes regarding the historical Juana of Castile, she did not manage her own household, and lacked both the financial resources and the personal charm to inspire loyalty among her staff (71).

14 The historical Felipe did reportedly strike Juana at this juncture and confine her to her chambers. Aram describes, "[a]ccording to Martire, Juana ordered the blonde locks of her husband's supposed lover severed. In retaliation, Philippe allegedly raised his hand against Juana" (76).

15 The term "gaslighting" refers to the British film Gaslight (1940) and the 1944 American remake of the same title, based on a Patrick Hamilton play Angel Street (1939) about a woman whose 
husband hides items to make her think she has misplaced them, and modulates the gas lights to convince her she is going crazy so that he can lock her up and pursue his criminal ambition.

${ }^{16}$ As Aram notes, the real Marquis of Denia, with Carlos's knowledge and permission, did in fact strive to keep Queen Juana ignorant of her father's death as well as that of her father-in-law: "The marquis even urged Juana to write the deceased Maximilian and Fernando - acts that would have testified to her 'madness.' Rather than accepting such a trap, in both cases Juana requested that Denia write on her behalf" (123). Thus in spite of these concerted efforts to deceive her, "Juana appeared to question aspects of the fictional enclosure that Denia and Charles created for her" (124).

${ }^{17}$ Aram discusses at length the elaborate scheme of deception implemented by the historical Marquis of Denia with the approval of the Emperor Carlos V:

The correspondence between Denia and Charles reveals that the king and the marquis developed a complex strategy to govern Juana and her kingdoms by minimizing communication between them. Denia's efforts to isolate the queen entailed restricting her movements, controlling the people around her, and shaping the information that she received about the outside world. Although Charles encouraged the marquis to deceive his mother, the king approved the use of physical force against Juana only as a last resort. [...] With the king's approval, Denia invented a fictional world for Juana. (120)

This fictional world created to "gaslight" Juana thus could be interpreted as a cause rather than an effect of her alleged madness.

18 This connection between Juana's alleged inability to self-govern and her inability to govern Spain is articulated by an early twentieth-century historian: "Experts might now term Juana's malady hysteria rather than insanity, but there is no question that she was unfit to rule her country; she could not even command herself" (Armstrong 27).

\section{Works Cited}

Aram, Bethany. Juana the Mad: Sovereignty and Dynasty in Renaissance Europe. Baltimore and London: The Johns Hopkins UP, 2005.

Armstrong, Edward. 1910. The Emperor Charles V. 2 vols. London: Macmillan. Vol. 1.

Boling, Becky. "The Spectacle of the Other: Madness in Falsa crónica de Juana la Loca." Gestos 8 (1989): 87-97.

Brumberg, Joan Jacobs. Fasting Girls: The Emergence of Anorexia Nervosa as a Modern Disease. Cambridge: Harvard UP, 1988.

Diosdado, Ana. Los comuneros. Madrid: Preyson, 1993.

Gallop, Jane. The Daughter's Seduction: Feminism and Psychoanalysis. Ithaca: Cornell UP, 1982.

Gaslight. Dir. Thorold Dikinson. 1940.

Gaslight. Dir. George Cukor. 1944.

Halsey, Martha. "Juana La Loca in Three Dramas of Tamayo y Baus, Galdós, and Martín Recuerda.” Modern Language Studies 9.1 (1978-1979): 47-57.

Hamilton, Patrick. Angel Street. London: Samuel French, 1939. 
Magnarelli, Sharon. "Dramatic Irony and Lyricism in Historical Theatre: El pobre Franz and Falsa crónica de Juana la loca." Latin American Theatre Review 22.2 (1989): 47-58.

Martín Recuerda, José. El engañao. Caballos desbocaos. Ed. Martha T. Halsey and Angel Cobo. Madrid: Cátedra, 1981.

Pérez Galdós, Benito. Santa Juana de Castilla. Cuentos y teatro. Ed. Federico Carlos Sainz de Robles, 954-69. Madrid: Aguilar, 1971.

Romero, Concha. Razón de estado o Juego de reinas. Madrid: J. García Verdugo, 1997.

Rubin, Gayle. "The Traffic in Women: Notes on the Political Economy of Sex." Toward an Anthropology of Women. Ed. Rayna R. Reiter. New York: Monthly Review Press, 1975. 157-210.

Rueda, Manuel. Retablo de la pasión y muerte de Juana la Loca. Madrid: Ediciones de Cultura Hispánica, 1996.

Sabido, Miguel. "Algunas interrogantes sobre el texto." Falsa crónica de Juana la Loca. Mexico City: Katún, 1985. 7-11.

. Falsa crónica de Juana la Loca. Mexico City: Katún, 1985.

Sedgwick, Eve Kosofsky. Between Men: English Literature and Male Homosocial Desire. New York: Columbia UP, 1985.

Showalter, Elaine. The Female Malady: Women, Madness, and English Culture 1830-1980. New York: Pantheon, 1985.

Tamayo y Baus, Manuel. La locura de amor. Ed. Vera Helen Buck and Anne Von Bibra Sutton. New York and London: Century, 1931.

Vandereycken, Walter, and Ron Van Deth. From Fasting Saints to Anorexic Girls: The History of Self-Starvation. Washington Square New York: New York UP, 1994.

Zavalía, Alberto de. El corazón extraviado: Estampas de la vida de la reina doña Juana la Loca. Buenos Aires: Argentores Ediciones del Carro de Tespis, 1957. 